\title{
REVIEW LITERATURE: MENGKAJI PEMBERIAN PIJAT BAYI DENGAN MUROTTAL AL-QUR'AN UNTUK MENINGKATKAN DURASI TIDUR BAYI USIA 3-12 BULAN
}

\author{
Dian Wahyuningtyas ${ }^{1}$, Endang Susilowati ${ }^{2}$, Arum Meiranny ${ }^{3}$ \\ Program Studi Kebidanan Sarjana Kebidanan dan Pendidikan Profesi Bidan Fakultas Kedokteran \\ Universitas Islam Sultan Agung Semarang ${ }^{123}$ \\ e-mail: ${ }^{1}$ dianwtyas99@gmail.com, ${ }^{2}$ esusilowati@unissula.ac.id, ${ }^{3}$ arummeiranny@unissula.ac.id
}

\begin{abstract}
Introduction: Most babies (44.2\%) had sleep disturbances, and $72 \%$ of parents thought that this was not a significant problem. Sleep problems in babies are generally due to insufficient sleep in the baby. One of the efforts to improve baby sleep uration is by offering baby massage accompanied by the chanting of the Al-Qur'an murottal. Methods: International literature searched using electronic media by using several databases such as Google Scholar, Link Spinger and PubMed. The article used is 8 articles that discuss the effect of baby massage on baby sleep and the effect of listening to the Murottal Al-Quran on the duration of baby sleep. Results: There was a significant effect between infant massage and murottal Al-Qur'an on the increase in infant sleep duration. Discussion: One way to meet the sleep needs of babies is by increasing the duration of the baby's sleep. Efforts to increase sleep duration in babies can be done by giving baby massage accompanied by Al-Qur'an murottals. Baby massage can increase serotonin neurotansmiter levels, and listening to the murottal Al-Qur'an, the brain can produce neuropeptide substances so that it provides feedback in the form of a sense of comfort, safety, after that the baby's sleep will be more soundly. Conclusion: Baby massage with murottal Al-Qur'an is effective for increasing sleep duration in babies.
\end{abstract}

Keywords: Baby massage; Murottal; length of sleep for babies

\begin{abstract}
ABSTRAK
Pendahuluan: Sebagian besar bayi (44.2\%) mengalami gangguan tidur, dan $72 \%$ orang tua menganggap bahwa hal ini tidak menjadi masalah yang berarti. Masalah tidur pada bayi umumnya dikarenakan durasi tidur pada bayi yang kurang. Salah satu upaya untuk meningkatkan urasi tidur bayi adalah dengan pemberian pijat bayi diiring lantunan murottal Al-Qur'an. Metode: Literatur mancanegara yang ditelusuri menggunakan media elektronik dengan menggunakan beberapa databased seperti Google Scholar, Link Spinger dan PubMed. Artikel yang digunakan sebanyak 8 artikel yang membahas tentang pengaruh pijat bayi terhadap tidur bayi dan pengaruh menengarkan Murottal Al-Qur'an terhadap durasi tidur bayi. Hasil: Terdapat pengaruh yang signifikan antara pijat bayi dengan murottal Al-Qur'an terhadap peningkatan durasi tidur bayi. Pembahasan: Salah satu cara untuk memenuhi kebutuhan tidur pada bayi yaitu engan meningkatkan durasi tidur bayi. Upaya untuk meningkatkan durasi tidur pada bayi dapat dilakukan degan pemberian pijat bayi diiringi murottal Al-Qur'an. Pijat bayi dapat meningkatkan kadar neurotansmiter serotonin, dan mendengarkan murottal Al-Qur'an otak dapat memprouksi zat neuropeptide sehingga memberikan timbal balik berupa rasa nyaman, aman selanjurnya tidur bayi akan menjadi lebih nyenyak. Kesimpulan: Pijat Bayi dengan murottal Al-Qur'an efektif untuk meningkatkan durasi tidur pada bayi.
\end{abstract}

Kata kunci: Pijat bayi; Murottal; Lama tidur bayi

\section{PENDAHULUAN}

\section{Latar Belakang}

Pada 3 tahun pertama merupakan momen terpenting dimana sel-sel otak pada bayi berkembang serta mencapai $80 \%$ dari potensinya (1). Kebutuhan tidur pada bayi merupakan salah satu faktor yang dapat mempengaruhi pertumbuhan bayi, hal ini dikarenakan $75 \%$ hormon pertumbuhan diproduksi ketika bayi sedang tidur. Pertumbuhan serta perkembangan pada bayi sangat dipengaruhi oleh kualitas tidur bayi, hal ini disebabkan karena tidur mampunyai efek terhadap kesehatan fisik, mental dan emosional bayi. Kualitas tidur pada bayi apat dinilai dari kenyamanan tidur, cara tidur serta pola tidur pada bayi (2).

Masalah tidur pada bayi sebagian besar dikarenakan kurangnya durasi tidur sesuai dengan usianya (3). Di Indonesia sebanyak $44.2 \%$ bayi mengalami gangguan atau masalah tidur, sedangkan $72 \%$ orang tua menganggap bahwa hal ini tidak menjadi masalah padahal bayi yang mengalami masalah tidur sangat berdampak negatif pada pertumbuhan, diantaranya yaitu immunitas yang rentan, gangguan pada regulasi system endokrin serta dapat mengganggu pertumbuhan pada bayi (4). 
Tidur pada bayi dipengaruhi oleh beberapa faktor seperti kontak pada bayi, kecukupan pemberian ASI dan penggunaan dot pada bayi (5). Sedangkan menurut (6) terdapat dua faktor yang mempengaruhi gangguan tidur pada bayi yaitu faktor lingkungan seperti keberadaan aktivitas disekitar bayi, makan dan minum bayi. Faktor yang kedua adalah faktor kultural atau kebudayaan seperti kebiasaan tidur pada bayi.

Kurangnya tidur pada bayi dapat menimbulkan dampak fisiologi dan psikologi, dampak fisiologi diantaranya daya tahan tubuh yang menurun, lelah, lemah serta penurunan pola aktivitas pada bayi, sedangkan dampak psikologi meliputi kemampuan kognitif yang rendah, emosi yang tidak menentu, sulitnya konsentrasi serta bayi merasa cemas. Bayi yang mengalami gangguan tidur akan cenderung mudah sakit karena daya immunnya yang menurun, selain itu juga dapat berdampak pada pertumbuhan bayi seperti berat badan yang kurang, dan mempengaruhi tumbuh kembang bayi (Dewi, Nurman, \& Dhilon, 2013).

Bayi yang kurang tidur biasanya ditandai dengan perilaku rewel atau sering menangis ketika jam tidur, maka dari itu dibutuhkan sebuah sentuhan yang lembut sehingga dapat membuat bayi merasa nyaman serta dapat tertidur nyenyak, salah satu sentuhan tersebut adalah pijat bayi (Safitri, Suryani, \& Rahmi, 2016). Pijat bayi dapat meningkatkan kualitas tidur pada bayi, karena dengan diberikan pemijatan pada bayi maka tubuh bayi akan memproduksi kadar setotinin yang menghasilkan melatonin sehingga dapat membuat tidur bayi menjadi lebih lama (9). Terapi Murottal Al-Qur'an adalah terapi lantunan Al-Qur'an yang ketika seseorang di dengarkan lantunana tersebut akan memberikan dampak positif bagi tubuh. Murottal Al-Qur'an biasanya berupa audio yang dibacakan oleh seorang qori' atau pembaca Al-Qur'an (10). Murottal Al-Qur'an dapat memberikan efek ketenangan, karena ketika mendengarkan murottal Al-Qur'an otak akan mengalami relaksasi seolah-olah seperti dalam keadaan tertidur, sehingga akan mengirimkan sinyal ke kelenjar pituitary dan menghasilkan hormone endorphin yang memberikan timbal balik berupa ketenangan (Anam, Khasanah, \& Isworo, 2019).

\section{Tujuan Penelitian}

Tujuan dari penulisan ini adalah untuk membuktikan bahwa pijat bayi dengan iringan murottal Al-Qur'an dapat meningkatkan durasi tidur bayi sesuai dengan penelitian-penelitian sebelumnya yang telah dilakukan dengan cara mereview beberapa penelitian.

\section{METODE}

Penelitian ini dilakukan dengan cara mencari literature melalui media elektronik dengan menggunakan beberapa databased seperti Google Scholar, Link Spinger dan PubMed. Tujuan dari penulisan ini adalah untuk membahas tentang masalah kualitas tidur pada bayi. Kata kunci yang digunakan dalam penelusuran literature diantaranya "Baby Massagel Pijat bayi”, "Al-Qur'an", "Audio", dan "Kualitas tidur bayi". Artikel yang diperoleh dalam pencarian yaitu sebanyak 8 artikel yang terdiri dari 5 artikel internasional dan 3 artikel nasional kemudian selanjutnya dilakukan review.

\section{HASIL}

Artikel penelitian yang dilakukan oleh (3) dengan judul "Pengaruh Pijat Bayi Terhadap Peningkatan Lama Tidur Malam Pada Bayi 3-6 Bulan" yang menggunakan metode penelitian Pre-Eksperimental one grup pre test-post test desain, pengambilan sample dengan teknik Non-Probability Sampling hingga menapat jumlah sample sebanyak 10 bayi dengan usia 3-6 bulan. Pada penelitian ini dilakukan pijat bayi selama 8 minggu dengan frekuensi $3 x$ dalam satu minggu. Instrument yang digunakan adalah Baby Sleep Patten Chart, serta analisa data menggunakan uji deskriptif dan uji komparaso (Paried T-Test). Hasil penelitian menunjukkan bahwa pada uji beda terdapat nilai Significant $p=0,003$ dimana $\mathrm{p}<\alpha=(0,05)$, sehingga dapat ditarik kesimpulan bahwa ada efek pemberian pijat bayi terhadap lama tidur bayi 3-6 bulan sebelum dan sesudah pemijatan.

Artikel penelitan yang dilakukan oleh (12) dengan artikel yang berjudul "Pengaruh Pijat Bayi Terhadap Lama Tidur Bayi Usia 3-6 Bulan Di Desa Jemawan Kecamatan Jatinom Kabupaten Klaten" dengan menggunakan metode penelitian kuantitatif dan pendekatan quasy eksperiment serta pengambilan sample dilakukan dengan cara total sampling sehingga didapatkan sample sebanyak 32 responden. Instrumen yang digunakan pada penelitian ini yaitu dengan menggunakan lembar observasi, dimana ibu diminta untuk mengisi lembar tersebut sesuai dengan durasi tidur bayi dalam jam per hari. Data yang diperoleh dari penelitian ini akan dilakukan analisis univariat dengan uji Wiloxon. Hasil dari penelitian yang dilakukan diperoleh nilai $\mathrm{Z}-4,995$ dengan $p$ value (Asimp. Sig 2 tailed) sebesar 0,000 maka $p$ value $<0,005$, sehingga dapat ditarik kesimpulan bahwa terdapat pengaruh pijat tidur bayi terhadap lama tidur bayi usia 3-6 bulan.

Artikel penelitian yang dilakukan oleh (13) dengan judul penelitian "Pengaruh Terapi Murotal AlQur'an Terhadap Kualitas Tidur Bayi Usia 3-6 Bulan”. Jenis penelitian yang dilakukan adalah penelitian quasy eksperimen dengan one group pretest-posttest design, populasi pada penelitian ini adalah bayi usia 3-6 bulan dengan gangguan tidur dan teknik sampling menggunakan purposive sampling sehingga diperoleh responden sebanyak 16 bayi. Penelitian ini dilakukan dengan cara bayi didengarkan Murottal Al-Qur'an 2x sehari sebelum tiur, instrument yang digunakan adalah kuesioner gangguan kualitas tidur dan SOP terapi Murottal Al-Qur'an. Data yang diperoleh kemudian diujikan menggunakan uji Wilcoxon sign ranks test sehingga dipetoleh nilai $\mathrm{p}$ value $=0,000(\mathrm{p}<0,05)$ dan 
dapat disimpulkan bahwa terdapat pengaruh antara pemberian terapi Murottal Al-Qur'an dengan kualitas tidur bayi.

Artikel penelitian oleh (14) yang berjudul tentang "Influence of Baby Massage on Sleep Quality in Baby of 3-6 Months Age in Tirawuta Healt Center, East Kolaka District, Indonesia" Jenis penelitian yang digunakan adalah eksperimen semu one group pre testpost test desain, populasi dari penelitian ini sebanyak 23 bayi dan pengambilan sample dilakukan dengan tekning simple random sampling sehingga diperoleh sample sebanyak 13 responden. Pengumpulan data penenlitian menggunakan kuesioner, kemudian hasil data akan diuji menggunakan uji paired $\mathrm{T}$ test. Hasil dari penelitian ini didapat nilai $\mathrm{t}$ nilai $>\mathrm{t}$ tabel $=3,742$ $>$ 1,536 dimana t table untuk df 12 dengan signifikasi $0,003<0,02$ yang artinya bahwa setelah diberikan pijat bayi selama 4 minggu dengan frekuensi $3 x$ dalam satu minggu dan durasi selama 10-20 menit mempengaruhi lama tidur bayi.

Artikel penelitian selanjutnya yang dilakukan oleh (15) dengan judul "Effect of Massage on Behavioural Responses of Preterm Infacts in a Educational Hospital in Iran" penelitian yang dilakukan pada tahun 2019 ini menggunakan metode penelitian quasy eksperimen dengan metode one group pre test-post test. Sample dari penelitian ini yaitu sebanyak 45 bayi, metoe pengambilan data dilakukan dengan cara observasi secara langsung, hasil dari data yang diperoleh akan dilakukan uji ANOVA. Hasil dari penelitian menunjukkan bahwa nilai $\mathrm{p}=0,003$, sehingga disimpulkan bahwa terdapat pengaruh pijat bayi dengan lama tidur bayi.

Artikel penelitian yang dilakukan oleh (16) yang berjudul "The Effect of Baby Massage Toward Baby Sleep Quantity on He Age of 3-6 Months in South Sempaja Sub-District, North Samarinda in 2019" Dengan menggunakan metode penelitian preeksperimental dan desain penelitian one group pre testpost test desain, teknik pengambilan sample pada penelitian ini menggunakan teknik Non-probability dengan teknik purposive sampling sehingga diperoleh jumlah responden sebanyak 18 bayi berusia 3-6 bulan. Pengumpulan data pada penelitian ini menggunakan lembar observasi, kemudian data diolah dengan uji statistik paried t-test dan diperoleh hasil nilai $\mathrm{p}=0,000$ dan dapat ditarik kesimpulan bahwa pijat bayi dapat mempengaruhi kualitas tidur bayi, salah satunya adalah lama tidur bayi, hal ini terbukti dengan adanya peningkatan lama tidur bayi yang mencapai 13,77 jam/hari dibandingkan dengan sebelum pijat yaitu $12,42 \mathrm{jam} /$ hari dengan rata-rata peningkatan urasi tiur selama 1,29jam/hari.

Artikel penelitian yang dilakukan oleh (17) dengan judul penelitian "Massage-base Bedtime Routine: Impact on Sleep and Mood in Infact and Mothers" yang menggunakan sample sebanyak 123 keluarga dengan bayi usia 3-18 bulan dan pengambilan sample secara acak. Pengukuran data yang digunakan untuk mengukur tidur bayi adalah kuesioner Brief
Infant Sleep Questionnaire (BISQ), bayi diberikan pemijatan selama 2 minggu, kemudian hasil data diolah menggunakan uji $\mathrm{T}$ sample independent dan uji chi square. Pada penelitian ini menjelaskan bahwa bayi yang diberikan intervensi mengalami penurunan jumlah bangun saat tidur. Dari hasil pengujian maka didapat nilai $\mathrm{p}=0,006$ yang artinya bahwa terdapat pengaruh pijat bayi dengan tidur bayi.

Penelitian yang dilakukan (18) dengan judul penelitian "Effect Baby Massage Using Lavender Aromatherapy in Fulfillment of Sleep Need Among Baby Age 6-12 Months in the Working Area Nilamsari Healt Center Bukittinggi 2017" jenis penelitian ini adalah quasy eskperimen dengan two group design. Sampel dari penelitian ini berjumlah 20 responden dengan 10 responden untuk kelompok 1 dan 10 responden untuk kelompok 2. Pada kelompok 1 diberikan pijat bayi tanpa aroma therapy, dan kelompok 2 diberikan pijat bayi dengan aromatherapy. Pengolahan data pada penelitian ini menggunakan uji T-Test dependent (Paried Sample T-Test), sehingga diperoleh nilai $\mathrm{p}=0,000(\mathrm{p}<0,05)$ dengan kesimpulan terdapat hubungan antara pijat bayi dengan menggunakan aroma therapy lavender. Bayi yang dipijat dengan iberikan aroma therapy lavender mempunyai peningkatan durasi tidur 2,8 jam, sedangkan bayi yang dipijat tanpa aroma therapy lavender mengalami peningkatan durasi tidur selama 2,55 jam.

\section{PEMBAHASAN}

Dari literature review beberapa jurnal maka dapat disimpulkan bahwa pijat bayi dengan murottal Al-Qur'an dapat meningkatkan durasi lama tidur bayi. Banyak sekali faktor yang mempengaruhi tidur pada bayi, salah satunya adalah emosional atau bayi merasa gelisah, dengan diberikan pijat bayi diiringi murottal Al-Qur'an maka bayi akan merasa rileks dan nyaman sehingga durasi tidur bayi dapat meningkat dan kebutuhan tidurnya terpenuhi.

Pijat bayi merupakan salah satu cara pengasuhan anak secara tradisional yang banyak sekali manfaatnya, bahkan bayi premature yang berikan pijat bayi 3-10 hari dapat memberikan efek berupa peningkatan berat badan sebanyak 50\%. Depresi dan kecemasan pada bayi akan cenderung menurun setelah diberikan pemijatan selama 30 menit sehari, selain itu dengan bayi yang merasa rileks maka tidur bayipun akan bertambah nyenyak (19).

Pijat bayi dapat meningkatkan kadar neurotransmitter serotonin yang dapat membuat serta meningkatkan kapasitas sel reseptor dan mengikat adrenalin atau glucocorticoid sehingga hormone stress dapat menurun dan memberikan timbal balik berupa rasa nyaman selanjutnya daya tahan tubuh akan meningkat. Selain itu manfaat dari pijat bayi antara lain menaikkan berat badan, menyerap makanan lebih baik lagi, menstimulasi produksi hormon oksitosin dan 
endorfin serta meningkatkan kesiagaan dan kewaspadaan (19).

Selaras dengan penelitian (3) yang dilakukan pada bayi dengan usia 3-6 bulan dan diberikan terapi pijat bayi, dengan hasil bahwa pijat bayi dapat meningkatkan lama tidur atau durasi tidur pada bayi. Peningkatan lama tidur pada bayi yang diberikan pijat bayi disebabkan oleh kadar sekresi serotonin yang dapat meningkat akibat dari pemijatan yang diberikan, selain itu terjadi perubahan pada gelombang otak, yaitu peningkatan gelombang beta dan tetra serta penurunan gelombang alfa. Serotonin dapat menekan aktivitas system pengaktivasi retikularis serta aktivitas otak lainnya sehingga padat membantu pembentukan tidur. Serotonin disintesis melalui asam amino tripthophan untuk diubah menjadi 5-hidroksittithophan (5HTP) sehingga menjadi $\mathrm{N}$-asetil serotonin dan akhhirnya berubah menjadi melatonin. Melatonin ini berperan untuk membuat tidur lebih lama dan lelap (9).

Penelitian (18) juga membuktikan bahwa pijat bayi dapat meningkatkan durasi tidur bayi, namun terdapat perbedaan durasi tidur bayi, hal ini disebebkan oleh beberapa faktor seperti lingkungan bayi dan pola asuh orang tua. Keadaan lingkungan bayi dapat mempengaruhi bagaimana bayi dapat tertidur dengan lelap atau tidak, lingkungan yang terlalu bising atau berisik dapat mengganggu istirahat dan tidur bayi sehingga bayi akan sulit untuk tidur. Pola asuh orang tua juga termasuk faktor bayi untuk tertidur, terkadang orang tua membiasakan bayinya untuk tidur terlalu malam, sehingga bayi dapat mngurangi durasi tidurnya. Keadaan bayi yang lelah dan stress akan membuat bayi menjadi lebih rewel dan susah tidur.

Suara dapat menurunkan hormone stress, meningkatkan rasa yang rileks, mengalikan perhatian serta mengaktifkan hormon endorphin alami sehingga memberikan efek ketenangan dan pengendalian emosi yang lebih baik (20). Menurut (21) yang mengutip dari penelitian Al-Kaheel (2012) menerangkan bahwa mendengarkan murottal Al-Qur'an dapat mempengaruhi sel elektromagnetik, sehingga dapat merangsang produksi zat kimia yang disebut neuropeptide sehingga menimbulkan efek nyaman kenyamanan serta kenikmatan.

Sesuai dengan penelitian (13) bahwa dengan terapi murottal Al-Qur'an dapat meningkatkan durasi tidur pada bayi. Hal ini disebabkan karena terapi murottal Al-Qur'an mempunyai efek samping yang sama dengan pijat bayi, yaitu meningkatkan produksi serotonin dan mengubahnya menjadi melatonin sehingga durasi tidur pada bayi juga dapat meningkat. Kebutuhan tidur anak yang terpenuhi akan mempengaruhi tumbuh kembang otak anak selanjutnya sehingga anak akan menjadi cerdas, berpikiran jernih dan berakal. Semua sel yang ada dalam tubuh akan diperbaiki dan diperbaharui oleh hormone pertumbuhan, yang proses pembaharuan ini berjalan ketika anak terlelap dari saat bangun.

Tempo yang lambat dan harmonis pada murottal Al-Qur'an inilah yang dapat menurunkan hormone stress, serta meningkatkan produksi hormon endorphin alami (serotonin) sehingga seseorang dapat merasa rileks, menurunkan rasa tegang, cemas, takut dan memperbaiki system kimia pada tubuh, sehingga murottal Al-Qur'an dipercaya memiliki potensi untuk meningkatkan kualitas tidur (13). Pada penelitian lain seperti penelitian (10) juga telah membuktikan bahwa murottal Al-Qur'an dapat meningkatkan kualitas atau lama tidur, meskipun surat yang digunakan untuk terapi berbeda-beda namun ternyata hasil dari penelitian tersebut tetap sama yaitu dapat mengatasi masalah tidur sehingga durasi tidur dapat meningkat.

\section{KESIMPULAN}

Berdasarkan literature review yang telah dilakukan oleh penulis, maka dapat ditarik suatu kesimpulan bahwa kualitas tidur pada bayi penting untuk diperhatikan, gangguan tidur pada bayi biasanya paling sering pada durasi tidur bayi, hal ini dapat berdampak buruk pada pertumbuhan dan perkembangan bayi. Salah satu upaya untuk meningkatkan kualitas tidur pada bayi dapat dilakukan dengan pijat bayi dan diiringi lantunan murottal AlQur'an. Penerapan pijat bayi dengan murottal AlQur'an dapat memberikan umpan balik berupa rasa nyaman dan rileks, sehingga kebutuhan tidur bayi dapat terpenuhi. Terjadi peningkatan durasi tidur bayi setelah diberikan pijat bayi $\mathrm{p}=0,000(\mathrm{p}<0,05)$. Terjadi peningkatan durasi tidur bayi setelah diberikan terapi murottal Al-Qur'an $p=0,000 \quad(p<0,05)$. Pijat bayi dengan murottal Al-Qur'an efektif untuk meningkatkan durasi tidur bayi.

Saran untuk literature review selanjutnya diharapkan dapat menggunakan databased yang lebih banyak lagi, kemudian artikel yang digunakan lebih relevan serta menggunakan artikel yang kurang dari 5 tahun terakhir agar rujukan yang digunakan lebih update.

\section{DAFTAR PUSTAKA}

1. Yuniarti S. Asuhan Tumbuh Kembang Neonatus Bayi, Balita dan Anak Pra Sekolah. Bandung: PT. Refika Aditama; 2015.

2. Santi E. Buku Pintar Pijat Bayi untuk Tumbuh Kembang Optimal Sehat dan Cerdas. Yogyakarta: Pinang Merah Publisher; 2012.

3. Permata A. Pengaruh Pijat Bayi Terhadap Peningkatan Lama Tidur Malam Pada Bayi 3 - 6 Bulan Effects of Baby Massage to Improvement of Long Night Sleep on Baby 3-6 Months. 2017;(2):37-45.

4. Putra RS. Tips Sehat dengan Pola Tidur Tepat dan Cerdas. Yogyakarta: Buku Biru; 2011.

5. Hitchcock SC. An Update on Safe Infant Sleep. Nurs Womens Health [Internet]. 2017;21(4):307-
11 .
Available
from: 
http://dx.doi.org/10.1016/j.nwh.2017.06.007

6. Wong F, Etila I. Smart Punktur. Jakarta: Penebar Plus; 2011.

7. Dewi YC, Nurman, Dhilon DA. Pengaruh Pijat Bayi Terhadap Kualitas Tidur Bayi Usia 6-12 Bulan Di Roemah Mini Baby Kids \& Mom Care Siak. 2020;4(2):79-90.

8. Safitri F, Suryani L, Rahmi N. Pengaruh Pijat terhadap Durasi Tidur Bayi di Desa Alue Naga Kecamatan Syiah Kuala Kota Banda Aceh. J Healthc Technol Med. 2016;2(1):29-34.

9. Utami R. Pedoman Pijat Bayi. Jakarta: Trubus Agriwidya; 2013.

10. Aprilini M, Mansyur AY, Ridfah A. Efektivitas Mendengarkan Murottal Al-Quran Dalam Menurunkan Tingkat Insomnia Pada Mahasiswa. Psikis J Psikol Islam. 2019;5(2):146-54.

11. Anam A, Khasanah U, Isworo A. Terapi Audio dengan Murottal Alquran Terhadap Perilaku Anak Autis: Literatur Review. 2019;39(8):822-3.

12. Kurniasari DD, Istikomah $\mathrm{H}$, Siswiyati. Pengaruh Pijat Bayi Terhadap Lama Tidur Bayi Usia 3-6 Bulan di Desa Jemawan Kecamatan Jatinom Kabupaten Klaten. J Kebidanan dan Kesehat Tradis. 2020;5(1):14-22.

13. Amalu C, Maftuchah, Ulya FH. Pengaruh Terapi Murrotal Al-Qur'an terhadap Kualitas Tidur Bayi Usia 3-6 Bulan. Wind Midwifery J. 2020;01(01):24-30.

14. Wahyuni S, Lestari SA, Zoahira WOA, Masriwatii S, Hoon LS. Influence of baby massage on sleep quantity in baby of 3-6 months age in Tirawuta health center, East Kolaka District, Indonesia. Enferm Clin [Internet]. 2020;30(2019):224-7. Available from: https://doi.org/10.1016/j.enfcli.2019.11.060

15. Baniasadi H, Hosseini SS, Abdollahyar A, Sheikhbardsiri H. Effect of massage on behavioural responses of preterm infants in an educational hospital in Iran. J Reprod Infant Psychol [Internet]. 2019;37(3):302-10. Available from:

https://doi.org/10.1080/02646838.2019.1578866

16. Noorbaya S, Siti Saidah RNM. the Effect of Baby Massage Toward Baby Sleep Quantity on the Age of 3-6 Months in South Sempaja Sub-District, North Samarinda in 2019. Malaysian J Med Res. 2020;04(01):37-42.

17. Mindell JA, Lee CI, Leichman ES, Rotella KN. Massage-based bedtime routine: impact on sleep and mood in infants and mothers. Sleep Med [Internet]. 2018;41:51-7. Available from: https://doi.org/10.1016/j.sleep.2017.09.010

18. Afriyanti D. Effects of Baby Massage Using Lavender Aromatherapy in Fulfillment of Sleep Need Among Baby Age 6-12 Months in the. Journal [Internet]. 2018;3(1):24. Available from: https://doi.org/10.25077/jom.1.1.13-24.2018

19. Suwardini F. Jurus Sakti Menguasai Pijat Bayi. Jakarta: HB; 2013.
20. Widiastuti A, Rusmini R, Mulidah S, Haryati W. Terapi Dzikir Dan Murottal Untuk Mengurangi Kecemasan Pada Pre Eklampsia Ringan. Link. 2018;14(2):98.

21. Nugrahehi N, Romdiyah. Perbedaan Perlakuan Senam Hamil dan Terapi Murotal terhadap Penurunan Tingkat Kecemasan Ibu Hamil Trimester III. J PPKM II. 2018;226-36. 